\title{
Two new cheirosporous asexual taxa (Dictyosporiaceae, Pleosporales, Dothideomycetes) from freshwater habitats in Egypt
}

\begin{abstract}
Abdel-Aziz FA
Department of Botany and Microbiology, Faculty of Science, Sohag University, Sohag 82524, Egypt

Abdel-Aziz FA 2016 - Two new cheirosporous asexual taxa (Dictyosporiaceae, Pleosporales, Dothideomycetes) from freshwater habitats in Egypt. Mycosphere 7(4), 448-457, Doi 10.5943/mycosphere/7/4/5
\end{abstract}

\begin{abstract}
Cheirosporium vesiculare and Dictyosporium palmae spp. nov. were collected from submerged wood in the River Nile, Sohag, Egypt. Cheirosporium vesiculare is characterized by macronematous conidiophores, and non-complanate conidia, that are circular in vertical view with seven rows arranged in six peripheral rows and one in the center. Conidia are equipped with 2 to 5 balloon-like large appendages with long necks that penetrate through the peripheral rows and connect to the central row. Phylogenetic analyses of LSU sequence data place $C$. vesiculare in a monophyletic clade with $C$. triseriale in the family Dictyosporiaceae. Dictyosporium palmae is distinguished from the previously described species by its different conidial dimensions and the variable shapes of the gelatinous conidial appendages. Phylogenetic analyses of LSU sequence data place $D$. palmae in Dictyosporium sensu sticto in a clade with $D$. digitatum and $D$. stellatum with high statistical support.
\end{abstract}

Key words - Cheirosporium - Dictyosporium - lignicolous fungi - taxonomy - phylogeny

\section{Introduction}

In an ongoing study of freshwater fungi in River Nile in Egypt (Abdel-Aziz \& Abdel-Wahab 2010, Liu et al. 2015, Ariyawansa et al. 2015, Li et al. 2016), two undescribed cheirosporous taxa were collected from submerged wood in the River Nile, Sohag, Egypt. The two new taxa are described, illustrated and compared with similar taxa in this article. Cai et al. (2008) established Cheirosporium to accommodate $C$. triseriale L. Cai \& K.D. Hyde that is characterized by the production of sporodochial conidiomata, semi-macronematous to macronematous conidiophores that possess several distinct sterile branches, and cheiroid, smooth-walled conidia with rhexolytic secession.

Corda (1836) established the genus Dictyosporium to accommodate D. elegans Corda. Species of the genus produce sporodochia and holoblastic, solitary, cheiroid conidia on micronematous conidiophores. Dictyosporium species are cosmopolitan fungi growing as saprobes on decaying plant debris in freshwater and terrestrial habitats. Conidiophores are micronematous or absent. Goh et al. (1999) reviewed the genus Dictyosporium and accepted 22 species and dichotomous keys were provided for Dictyosporium species (Goh et al. 1999, Cai et al. 2003b, Crous et al. 2009, Whitton et al. 2012, Silva et al. 2015). The genus currently contains 48 species of which 18 have been recorded with conidial appendages (Silva et al. 2015). Molecular phylogenetic 
analyses place Dictyosporium within the Pleosporales (Tsui et al. 2006, Crous et al. 2009, Liu et al. 2015, Tanaka et al. 2015) and a new family, Dictyosporiaceae Boonmee \& K.D. Hyde was recently described (Boonmee et al. 2016).

\section{Materials \& Methods}

\section{Collection of the fungi}

Decaying wood samples were collected from River Nile, Sohag governorate, Egypt. Samples were examined upon arrival to laboratory under stereomicroscope for fungal fruiting structures and incubated in humid plastic chambers. Wood samples were examined periodically over 3 month's incubation. Fungi were isolated, described and photographed and herbarium materials were prepared as described in Abdel-Aziz (2016). Voucher slides and type material of the new fungi were deposited at CBS-KNAW Fungal Biodiversity Centre, Netherlands and Mae Fah Luang University culture collection (MFLUCC), Thailand and the author's culture collection. Facesoffungi and Index Fungroum numbers are registered (Jayasiri et al. 2015, Index Fungorum 2016).

\section{DNA extraction, sequencing, and phylogenetic analysis}

Fungi were grown on liquid media, filtered and mycelium was washed twice with sterile distilled water in centrifuge. Total genomic DNA was extracted from the obtained mycelium using Microbial DNA extraction kit (MOBIO; Mo Bio Laboratories, Carlsbad, CA, USA) according to the manufacturer's instructions. LROR and LR7 primers were used for the amplification of partial LSU ribosomal DNA (Vilgalys \& Hester 1990). Sequencing was made by Macrogen Inc., Korea using MGTM Taq-HF DNA Polymerase; cycling parameters were as follow: initial denaturation at $96^{\circ} \mathrm{C}$ for $3 \mathrm{~min}, 96^{\circ} \mathrm{C}$ for $15 \mathrm{~s}, 52^{\circ} \mathrm{C}$ for $45 \mathrm{~s}, 72^{\circ} \mathrm{C}$ for $1 \mathrm{~min} 30 \mathrm{~s}$, and final elongation at $72^{\circ} \mathrm{C}$ for $7 \mathrm{~min}$. Sequencing reactions are performed in the DNA Engine Tetrad 2 Peltier Thermal Cycler (BIO- RAD) using the ABI BigDye(R) Terminator v3.1 Cycle Sequencing Kit (Applied Biosystems), following the protocols supplied by the manufacturer. Single-pass sequencing is performed on each template using LROR and LR7 primers for LSU sequence. The fluorescentlabeled fragments were purified by the method that Applied Biosystems recommends as it removes the unincorporated terminators and dNTPs. The samples are injected to electrophoresis in an ABI 3730xl DNA Analyzer (Applied Biosystems). Sequences were assembled using Sequencher 4.2.2 (Gene Codes Corporation). Blast searches at GenBank were carried out in order to get the closest taxa to the two fungi. Alignment of the sequences was carried out using ClustalX (Thompson et al. 1997) and manual adjustments were carried out when necessary. Representatives of Dictyosporiaceae and Didymosphaeriaceae were included in the phylogenetic analyses, while representatives of Lentitheciaceae were used as out group (Fig. 1). I tried to sequence the ITS rDNA of the two new fungi using different primers combination but it was not successful.

Phylogenetic analyses were carried out using PAUP* v. 4.0b10 (Swofford 2002). Maximumlikelihood analysis (Felsenstein 1981) was performed using heuristic searches with the random stepwise addition of 100 replicates and tree bisection-reconnection (TBR) rearrangements. The optimal model of nucleotide substitution for the ML analyses was determined using hierarchical likelihood ratio tests as implemented in Modeltest 3.7 (Posada \& Crandall 1998). The model selected as the best fit for LSU rDNA dataset was TrNef $+\mathrm{G}$. Maximum-parsimony (MP) trees were obtained by 100 random addition heuristic search replicates using phylogenetic packages, and 1000 bootstrap replicates were performed employing 5 random addition heuristic searches. Bayesian analyses were performed by using PAUP v. 4.0b10 (Swofford 2002) and MrBayes 3.1.2 (Huelsenbeck \& Ronquist 2001, Ronquist \& Huelsenbeck 2003). The model of evolution (SYM+G) was estimated by using MrModeltest 2.2 (Nylander 2004). Posterior probabilities (PP) were performed by Markov Chain Monte Carlo sampling (BMCMC) in MrBayes v. 3.0b4. Five million generations were run in four chains with sampling every 100 generations, yielding 50000 trees, of which the first 12500 trees, representing the burn-in phase of the analyses, were discarded 
and the remaining trees used for calculating posterior probabilities (PP) in the majority rule consensus tree. Produced phylogenetic analyses were visualized using Njplot (Perrière \& Gouy 1996).

\section{Results}

\section{Phylogenetic analyses}

Large subunit rDNA dataset comprising 29 taxa of which 22 belong to Dictyosporiaceae, four to Didymosphaeriaceae, three to Lentitheciaceae (Fig. 1). The maximum parsimony dataset consists of 500 characters with 197 characters as constant information, 234 characters as variable characters are parsimony-uninformative, and 69 characters were parsimony-informative characters. Thirteen most parsimonious trees were produced using a heuristic search with a tree length of 429 steps, a consistency index (CI) of 0.8135, a retention index (RI) of 0.7183 and a rescaled consistency index (RC) of 0.5844. Maximum likelihood analysis produced one tree ( - ln likelihood $=2347.76679$ ). Phylogenetic trees obtained from maximum parsimony and Bayesian analysis yielded trees with similar overall topology to MP phylogenetic tree shown in Fig. 1. Dictyosporium palmae nested within Dictyosporium sensu stricto in a highly supported clade, 73/61/95 for MP/ML Bayesian pp respectively along with $D$. digitatum J.L. Chen \& C.H. Hwang and D. stellatum G.P. White \& Seifert. Cheirosporium vesiculare clustered with $C$. triseriale in a monophyletic clade with low statistical support in a distal clade in Dictyosporiaceae Boonmee \& K.D. Hyde (Fig. 1).

\section{Taxonomy}

\section{Cheirosporium vesiculare Abdel-Aziz, sp. nov.}

Index Fungorum number: IF 552327

Facesoffungi number: FoF 02493

Etymology: From the Latin adjective vesiculare, in reference to the balloon-shape of the conidial appendages.

Holotype: MFLU 15-1513.

Saprobic on submerged wood. Sexual morph Undetermined. Asexual morph Mycelium immersed in the substrate, hyaline to yellow-brown, $2-4 \mu \mathrm{m}$ wide, septate. Sporodochia on natural substrata superficial, compact, circular or subglobose, dark-brown, $200 \mu \mathrm{m}$ to $1 \mathrm{~mm}$ diam. Conidiophores macronematous, yellow-brown to brown in color, 0-1 septate, straight or sinuate, branched or unbranched, 5-17 × 3-6 $\mu \mathrm{m}$. Conidiogenous cells monoblastic, determinate, hyaline to yellow-brown in color, globose, subglobose to ovate in shape, thin-walled, 5-15 $\mu \mathrm{m}$ diam, mostly remain attached to the conidia (Fig. 2e). Conidia solitary, digitate, non-complanate, clavate to ellipsoidal in frontal view, circular in vertical view (Fig. $2 \mathrm{k}, 1), 42-65 \times 19-22 \mu \mathrm{m}(\overline{\mathrm{x}}=55.8 \times 20.4$ $\mu \mathrm{m}, \mathrm{n}=50$ ), yellow-brown to brown, consisting of $71-85$ cells, individual cells are rectangular or discoid, 4-7 $\mu \mathrm{m}$ tall, 6-10 $\mu \mathrm{m}$ wide, larger in size toward the middle of the rows than cells in the upper or lower parts of the rows, arranged in 7 compact rows, 6 of which in peripheral positions and one central, each two rows are connected to large basal cell, 9-12 cells per row. Conidial secession is rhexolytic. Conidia are equipped with 2 to 5 large, globose to subglobose, balloon-like with long neck (Fig. 2h) that penetrate between outer rows and connect to the central row (Fig. $2 \mathrm{k}, 1)$. Conidial appendages are deciduous, hyaline, senescent appendages yellow-brown and septate (Fig. 2g).

Culture characters - Conidia germinating on PDA within $24 \mathrm{~h}$ and several germ tubes produced from each conidium. Colonies $15-20 \mathrm{~mm}$ diam. in two weeks at $23^{\circ} \mathrm{C}$, produce white mycelium with dull yellow reverse. No conidia or sexual stages were recorded.

Material examined - EGYPT, Sohag, River Nile, on submerged decaying wood, 25 January 2015, F.A. Abdel-Aziz, MFLU 15-1513, holotype; ex-type living culture, MFLUCC 15-0753, MD6006. 


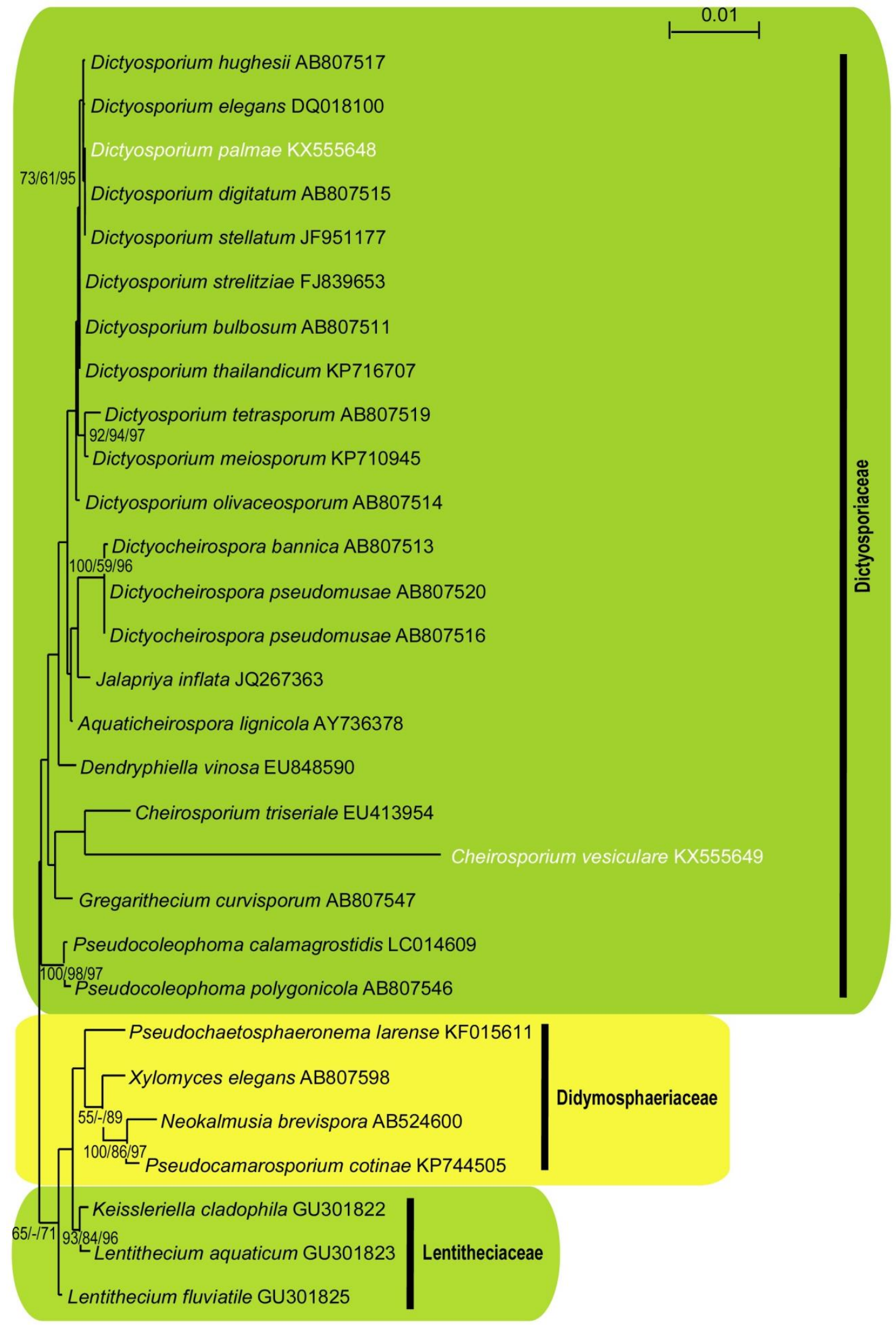

Fig. 1 - Phylogenetic relationships of the two new species with species and genera in Dictyosporiaceae based on the nucleotide sequences of LSU rDNA. Phylogenetic tree is one of the 13 equally most parsimonious trees obtained from LSU sequence data. (CI=0.8135, $\mathrm{RI}=0.7183, \mathrm{RC}=0.5844, \mathrm{HI}=0.1865$ ). Bootstrap support on the nodes represent MP, ML and Bayesian pp $\geq 50 \%$. The tree is rooted to representatives of Lentitheciaceae. New species are in white. 


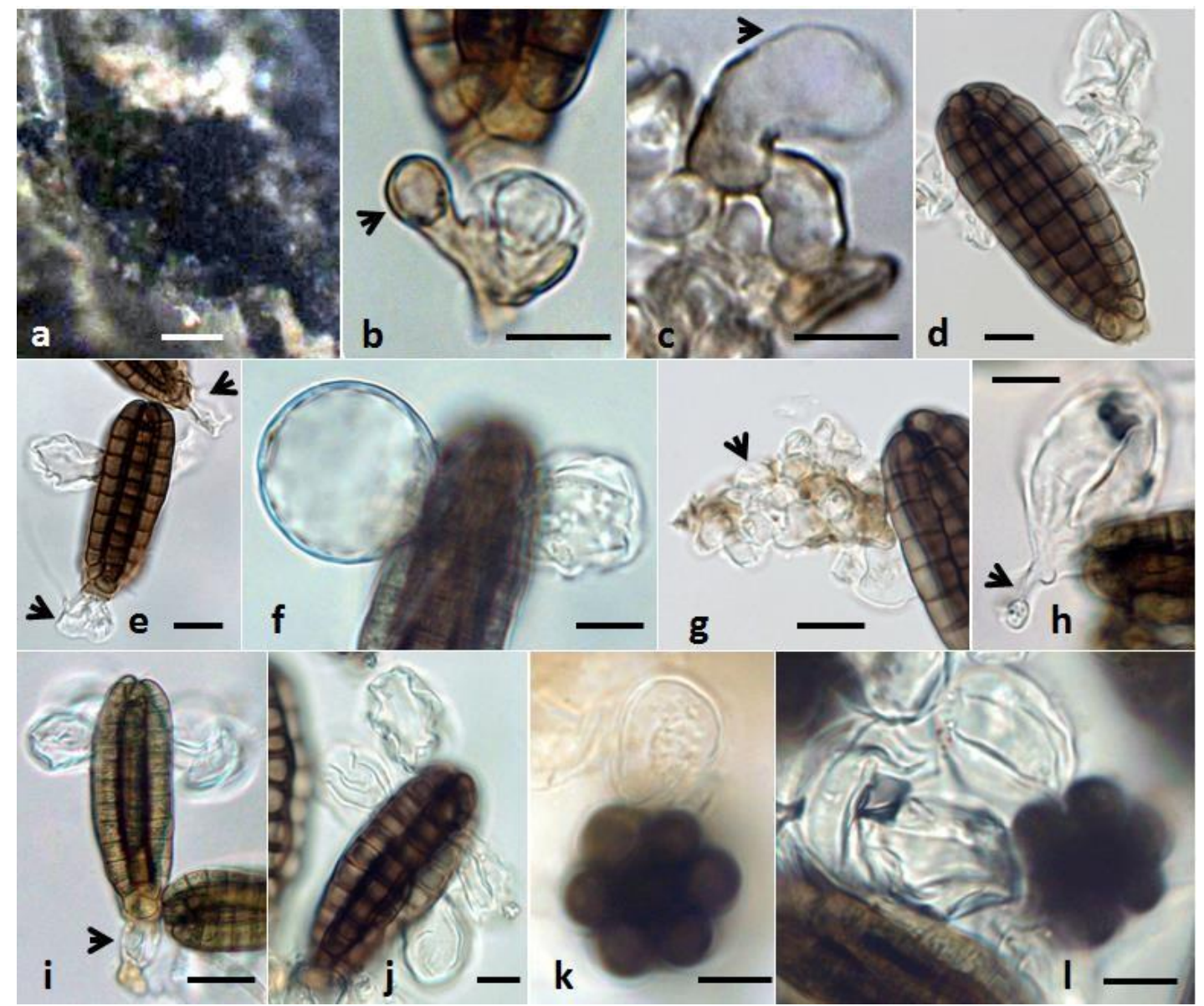

Fig. 2 - Cheirosporium vesiculare (holotype). a Compact sporodochium on wood. b,c Conidiophores and conidiogenous cells (arrowed). d,e Conidia with lateral appendages. Note the teared conidiogenous cell, arrowed in Fig. e. f,g Magnified apical part of the conidia showing the lateral appendages. Senescent appendages are yellow-brown in color and septate (arrowed in Fig. g). h Balloon-like appendage with long neck (arrowed). i,j Conidia with four lateral appendages, conidiogenous cell is arrowed in Fig. i). k,l Vertical view of the conidia showing the six peripheral rows and one central row and lateral appendages attached to the central row. Scale bars: $a=150$ $\mu \mathrm{m}, \mathrm{b}-\mathrm{l}=10 \mu \mathrm{m}$.

Notes - Phylogenetic analyses of LSU rDNA placed Cheirosporium vesiculare in a monophyletic clade with $C$. triseriale with low statistical support (Fig. 1). Both species form a distal clade in the newly described family, Dictyosporiaceae Boonmee \& K.D. Hyde (Boonmee et al. 2016) and sister clade to the sexual species Gregarithecium Kaz. Tanaka \& K. Hiray., Pseudocoleophoma Kaz. Tanaka \& K. Hiray. and the asexual species Dendryphiella vinosa (Berk. \& M. A. Curtis) Reisinger. Cheirosporium species produce macronematous conidiophores and typically rhexolytic secession of conidia. Cheirosporium species differ from Dictyosporium species by having macronematous conidiophores and are phylogentically distant from Dictyosporium sensu stricto clade (Fig. 1). C. triseriale differs from C. vesiculare by having sporodochial punctiform conidiomata, complanate conidia, without appendages and conidia with 3 cell rows (Cai et al. 2008). At morphology level, C. vesiculare is reminiscent of Dictyposporium musae Photita and $D$. tetraploides L. Cai \& K.D. Hyde in having hyaline, lateral appendages and overlap conidial dimensions (Photita et al. 2002, Cai et al. 2003a). However, $C$. vesiculare differs from the two species by having macronematous conidiophores, large hyaline conidiogenous cell, higher numbers of conidial appendages that are larger in size with long neck that penetrate through peripheral cell rows and connect to the central row and senescent appendages become yellow-brown and septate. No molecular data are available for D. musae and D. tetraploides at GenBank. 


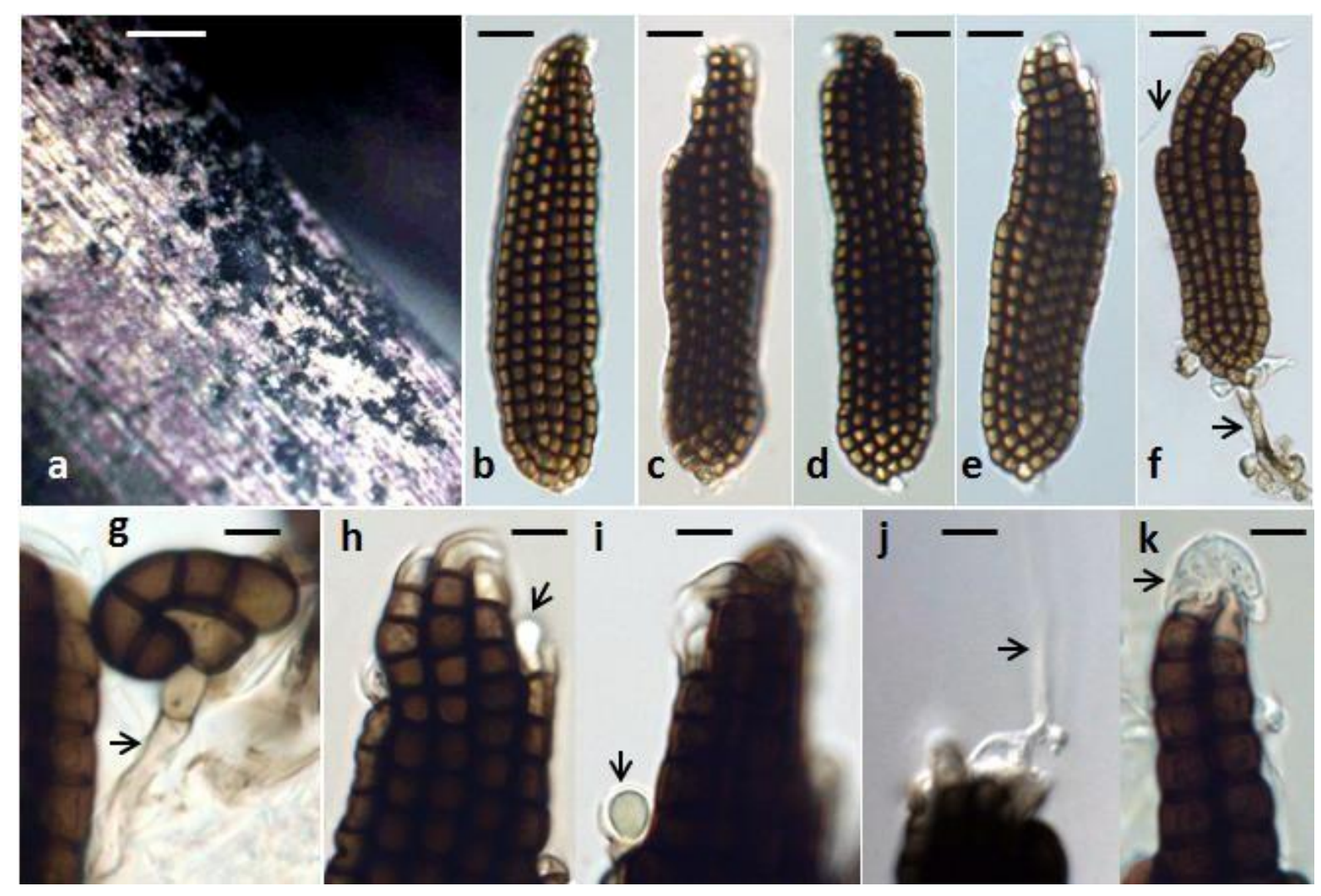

Fig. 3 - Dictyosporium palmae (holotype). a Diffuse sporodochia on wood. b-f Variously shaped conidia. g Young conidium. f,g Conidia from pure culture, conidiophores (arrowed). h-k Magnified apical part of the conidia showing variously shaped conidial appendages. Conidial appendages can be globose hyaline appendage surrounded by mucilaginous sheath (in $\mathrm{h}, \mathrm{j}$, arrowed), mucilaginous cap (in $\mathrm{k}$, arrowed) or long, hyaline, hyphae-like (in $\mathrm{f}, \mathrm{j}$, arrowed). Scale bars: $\mathrm{a}=150 \mu \mathrm{m}, \mathrm{b}-\mathrm{f}=10$ $\mu \mathrm{m}, \mathrm{g}-\mathrm{k}=5 \mu \mathrm{m}$.

Dictyosporium palmae Abdel-Aziz, sp. nov.

Index Fungorum number: IF552328

Facesoffungi number: FoF 02492

Etymology: From date palm, the host. Holotype: CBS-H 22129

Ex-type culture: CBS $139630=$ MF3178

Saprobic on submerged decaying fronds of Phoenix dactylifera (date palm). Sexual morph Undetermined. Asexual morph Mycelium immersed in the substrate, hyaline, 2.5-4 $\mu \mathrm{m}$ thick, septate. Conidiomata on the natural substrate sporodochial, loose, scattered, shining black, one to $10 \mathrm{~cm}$ in length. Conidiophores micronematous, hyaline to light-brown in color, 0-2 septate, 22-40 $\times 4-5 \mu \mathrm{m}$. Conidiogenous cells monoblastic, determinate, yellow-brown to brown in color, subglobose to ovate in shape, thin-walled, 10-17 $\times 7-10 \mu \mathrm{m}$. Conidia solitary, digitate, complanate, obclavate in shape with rounded base and tapered tip, 75-165 × 15-33 $\mu \mathrm{m}$ (x 107.02 $\times 26.4 \mu \mathrm{m}, \mathrm{n}$ =60), dark-brown to black, consisting of 95-144 cells, individual cells are cylindrical, elongated, 5-7 $\mu \mathrm{m}$ tall, 2.5-4 $\mu \mathrm{m}$ wide, arranged in 3-6 compact rows, 17-26 cells per row, the inner rows nested within the outer rows that mostly shorter than inner ones, tips of some rows are equipped with gelatinous, hyaline, rounded appendages (Fig. 3h,i) or hyaline, long, hypha-like appendages up to $50 \mu \mathrm{m}$ long and $3 \mu \mathrm{m}$ thick (Fig. 3f,j) or gelatinous caps to the whole conidial tip (Fig. 3k).

Culture characters - Conidia germinating on PDA within $24 \mathrm{~h}$ and several germ tubes produced from each conidium. Colonies $30 \mathrm{~mm}$ diam. in two weeks at $23^{\circ} \mathrm{C}$, produce white mycelium with orange liquid droplets on its surface with yellow to orange exudates. Sporulating after 3 months incubations and produce conidia similar in shape and size to those recorded on natural wood. 
Material examined - EGYPT, Sohag, River Nile, on submerged decaying fronds of Phoenix dactylifera L. (Arecaceae), 14 August 2014, F.A. Abdel-Aziz, CBS-H 22129, holotype; ex-type living culture, CBS $139630=$ MF3178.

Notes - Phylogenetic analyses of LSU rDNA placed Dictyosporium palmae in Dictyosporium sensu stricto along with the type species D. elegans in a highly supported clade with D. digitatum and D. stellatum (Fig. 1). D. palmae differs from $D$. digitatum by having longer and narrower conidia $(75-105 \times 18-32 \mu \mathrm{m}$ vs. $46.5-88 \times 26-46 \mu \mathrm{m})$ and a fewer cell rows (4-6 vs. 6-8 rows) for D. palmae and D. digitatum respectively (Goh et al. 1999). D. palmae differs from D. stellatum by having larger sporodochia (up to $10 \mathrm{~cm}$ length vs. $7 \mathrm{~mm}$ diam), narrower conidia (75-165 × 15-33 $\mu \mathrm{m}$ vs. 50-175 × 27.5-52.5 $\mu \mathrm{m}$ ), fewer cell rows (3-6 vs. 5-7) for D. palmae and D. stellatum respectively. Conidial appendages are absent in D. stellatum and their conidial cells are discoid or doliiform. Conidial cells in D. palmae are cylindrical or elongate in shape and conidia with appendages (Crous et al. 2011). Dictyosporium sensu stricto comprises the type species D. elegans and sixteen taxa which include fifteen asexual and two sexual species. Fungi belong to Dictyosporium sensu stricto are characterized by having effused and scattered colonies, pleurogenous irregular conidiophores, and olive to brown conidia with or without appendages. The two sexual morph strains are basal to the asexual strains and might represent a new genus (Boonmee et al. 2016).

\section{Acknowledgements}

This project is supported by Department of Botany and Microbiology, Faculty of Science, Sohag University. Dr. Shaun Pennycook is thanked for checking Latin names.

\section{References}

Abdel-Aziz FA, Abdel-Wahab MA. 2010 - Lolia aquatica gen. et sp. nov. (Lindgomycetaceae, Pleosporales), a new coelomycete from freshwater habitats in Egypt. Mycotaxon 114, 3342. http://dx.doi.org/10.5248/114.33

Abdel-Aziz FA. 2016 - The genus Lolia from freshwater habitats in Egypt with one new species. Phytotaxa 267, 279-288. http://dx.doi.org/10.11646/phytotaxa.267.4.4

Ariyawansa HA, Hyde KD, Jayasiri SC, Buyck B, Chethana KWT, Cui Y-Y, Dai DQ, Dai YC, Dinushani A, Daranagama DA, Jayawardena RS, Lücking R, Ghobad-Nejhad M, Niskanen T, Thambugala KM, Voigt K, Zhao RL, Boonmee S, Bahkali AH, Chen J, Cui BK, Dayarathne MC, Dissanayake AJ, Ekanayaka AH, Hashimoto A, Hongsanan S, Jones EBG, Larsson E, Lewis D, Li WJ, Li Q-R, Liu JK, Luo ZL, Maharachchikumbura SSN, Mapook A, McKenzie EHC, Norphanphoun C, Pang KL, Perera RH, Phookamsak R, Phukhamsakda C, Randrianjohany E, Senanayake IC, Singtripop C, Shang Q, Tanaka K, Tian Q, Tian CM, Tibpromma S, Verbeken A, Abdel-Wahab MA, Wanasinghe D, Wijayawardene NN, Zhang JF, Zhang H, Abdel-Aziz FA, Wedin M, Westberg M, Ammirati JF, Bulgakov TS, Lima DX, Callaghan TM, Callac P, Chang CH, Coca LF, Dal-Forno M, Dollhofer V, Fliegerová K, Greiner K, Griffith GW, Ho HM, Hofstetter V, Jeewon R, Kang JC, Wen TC, Kirk PM, Kytövuori I, Lawrey JD, Xing J, Li H, Liu ZY, Liu XZ, Liimatainen K, Thorsten Lumbsch H, Matsumura M, Moncada B, Nuankaew S, Parnmen S, Santiago ALCMDA, Sommai S, Song Y, de Souza CAF, de Souza-Motta CM, Su HY, Suetrong S, Wang Y, Fong WS, Yuan HS, Zhou LW, Réblová M, Fournier J, Camporesi E, Luangsa-ard JJ, Tasanathai K, Khonsanit A, Thanakitpipattana D, Somrithipol S, Diederich P, Millanes AM, Common RS, Stadler M, Yan JY, Li XH, Lee HW, Nguyen TTT, Lee HB, Battistin E, Marsico O, Vizzini A, Vila J, Ercole E, Eberhardt U, Simonini G, Wen HA, Chen XH, Miettinen O, Spirin V, Hernawati. 2015 - Fungal diversity notes 111-252-taxonomic and phylogenetic contributions to fungal taxa. Fungal Diversity 75, 27-274. http://dx.doi.org/10.1007/s13225015-0355-4 
Boonmee S, D'souza MJ, Luo Z, Pinruan U, Tanaka K, Su H, Bhat DJ, McKenzie EHC, Jones EBG, Taylor JE, Phillips AJL, Hirayama K, Eungwanichayapant PD, Hyde KD. 2016 Dictyosporiaceae fam. nov. Fungal Diversity 79, online. http://dx.doi.org/10.1007/s13225016-0363-Z

Cai L, Guo XY, Hyde KD. 2008 - Morphological and molecular characterisation of a new anamorphic genus Cheirosporium, from freshwater in China. Persoonia 20, 53-58.

Cai L, Zhang K, McKenzie EHC, Hyde KD. 2003a - New species of Dictyosporium and Digitodesmium from submerged wood in Yunnan, China. Sydowia 55: 129-135.

Cai L, Zhang K, McKenzie EHC, Lumyong S, Hyde KD. 2003b - New species of Canalisporium and Dictyosporium from China and a note on the differences between these genera. Cryptogamie Mycologie 24, 3-11.

Corda AC. 1836. Mykologische Beobachtungen. Weitenweber's Beitrage zur gesammten Naturund Heilwissenschaften. Prague.

Crous PW, Braun U, Wingfield MJ, Wood AR, Shin HD, Summerell BA, Alfenas AC, Cumagun CJR; Groenewald JZ. 2009 - Phylogeny and taxonomy of obscure genera of microfungi. Persoonia 22, 139-161. http://dx.doi.org/10.3767/003158509X461701

Crous PW, Groenewald JZ, Shivas RG, Edwards J, Seifert KA, Alfenas AC, Alfenas RF, Burgess TI, Carnegie AJ, Hardy GESJ, Hiscock N, Huberli D, Jung T, Louis-Seize G, Okada G, Pereira OL, Stukely MJC, Wang W, White GP, Young AJ, McTaggart AR, Pascoe IG, Porter IJ, Quaedvlieg W. 2011 - Fungal planet description sheets: 69-91. Persoonia 26, 108-156. http://dx.doi.org/10.3767/003158511X581723

Felsenstein J. 1981 - Evolutionary trees from DNA sequences: a maximum likelihood approach. Journal of Molecular Evolution 17, 368-376. http://dx.doi.org/10.1007/BF01734359

Goh TK, Hyde KD, Ho WH, Yanna. 1999. A revision of the genus Dictyosporium with descriptions of three new species. Fungal Diversity 2, 65-100.

Huelsenbeck JP, Ronquist F. 2001 - MRBAYES: Bayesian inference of phylogeny. Bioinformatics 17, 754-755. http://dx.doi.org/10.1093/bioinformatics/17.8.754

Index Fungorum (2016) Index Fungorum. Available from: http://www.indexfungorum.org/names/Names.asp (accessed 14 July 2016)

Jayasiri, S.C., Hyde, K.D., Ariyawansa, H.A., Bhat, J., Buyck, B., Cai, L., Dai Y.C., Abd-Elsalam, K.A., Ertz, D., Hidayat, I., Jeewon, R., Jones, E.B.G., Bahkali, A.H., Karunarathna, S.C., Liu, J.K., Luangsa-ard, J.J., Lumbsch, H.T., Maharachchikumbura, S.S.N., McKenzie, E.H.C., Moncalvo, J.M., Ghobad-Nejhad, M., Nilsson, H., Pang, K.L., Pereira, O.L., Phillips, A.J.L., Raspé, O., Rollins, A.W., Romero, A.I., Etayo, J., Selçuk, F., Stephenson, S.L., Suetrong, S., Taylor, J.E., Tsui, C.K.M., Vizzini, A., Abdel-Wahab, M.A., Wen, T.C., Boonmee, S., Dai, D.Q., Daranagama, D.A., Dissanayake, A.J., Ekanayaka, A.H., Fryar, S.C., Hongsanan, S., Jayawardena, R.S., Li, W.J., Perera, R.H., Phookamsak, R., Silva, N.I., Thambugala, K.M., Tian, Q., Wijayawardene, N.N., Zhao, R.L., Zhao, Q., Kang, J.C. \& Promputtha, I. (2015) The Faces of Fungi database: fungal names linked with morphology, phylogeny and human impacts. Fungal diversity 74 (1): 3-18. http://dx.doi.org/10.1007/s13225-015-0351-8

Li GJ, Hyde KD, Zhao RL, Hongsanan S, Abdel-Aziz FA, Abdel-Wahab MA, Alvarado P, AlvesSilva G, Ammirati JF, Ariyawansa HA, Baghela A, Bahkali AH, Beug M, Bhat DJ, Dimitar Bojantchev D, Boonpratuang T, Bulgakov TS, Camporesi E, Boro MC, Ceska O, Chakraborty D, Chen JJ, Chethana KWT, Chomnunti P, Consiglio G, Cui BK, Dai DQ, Dai YC, Daranagama DA, Das K, Dayarathne MC, De Crop E, De Oliveira RJV, de Souza CAF, de Souza JI, Dentinger BTM, Dissanayake AJ, Doilom M, Drechsler-Santos ER, Ghobad- Nejhad M, Gilmore SP, Góes-Neto A, Gorczak M, Haitjema CH, Hapuarachchi KK, Hashimoto A, He MQ, Henske JK, Hirayama K, Iribarren MJ, Jayasiri SC, Jayawardena RS, Sun Jeong Jeon, Gustavo H Jerônimo, Ana L Jesus, EB Gareth Jones, Ji Chuan Kang, Karunarathna SC, Kirk PM, Konta S, Kuhnert E, Langer E, Lee HS, Lee HB, Li WJ, Li XH, Liimatainen K, Lima DX, Lin CG, Liu JK, Liu XZ, Liu ZY, Luangsaard JJ, 
Lücking R, Lumbsch HT, Lumyong S, Leaño EM, Marano AV, Matsumura M, McKenzie EHC, Mongkolsamrit S, Mortimer PE, Nguyen TTT, Niskanen T, Norphanphoun C, O’Malley MA, Parnmen S, Pawłowska J, Perera RH, Phookamsak R, Phukhamsakda C, Pires-Zottarelli CLA, Raspé O, Reck MA, Rocha SCO, de Santiago ALCMA, Senanayake IC, Setti L, Shang QJ, Singh SK, Sir EB, Solomon KV, Song J, Srikitikulchai P, Stadler M, Suetrong S, Takahashi H, Takahashi T, Tanaka K, Tang LP, Thambugala KM, Thanakitpipattana D, Theodorou MK, Thongbai B, Thummarukcharoen T, Tian Q, Tibpromma S, Verbeken A, Vizzini A, Vlasák J, Voigt K, Wanasinghe DN, Wang Y, Weerakoon G, Wen HA, Wen TC, Wijayawardene NN, Wongkanoun S, Wrzosek M, Xiao YP, Xu JC, Yan JY, Yang J, Yang SD, Hu Y, Zhang JF, Zhao J, Zhou LW, Peršoh D, Phillips AJL, Maharachchikumbura SSN. 2016 - Fungal diversity notes 253-366: taxonomic and phylogenetic contributions to fungal taxa. Fungal Diversity 78, 1-237. http://dx.doi.org/10.1007/s13225-016-0366-9

Liu JK, Hyde KD, Jones EBG, Ariyawansa HA, Bhat DJ, Boonmee S, Maharachchikumbura SSN, Mckenzie EHC, Phookamsak R, Phukhamsakda C, Shenoy BD, Abdel-Wahab MA, Buyck B, Chen J, Chethana KWT, Singtripop C, Dai DQ, Dai YC, Daranagama DA, Dissanayake AJ, Doilom M, D’souza MJ, Fan XL, Goonasekara ID, Hirayama K, Hongsanan S, Jayasiri SC, Jayawardena RS, Karunarathna SC, Li WJ, Mapook A, Norphanphoun C, Pang KL, Perera RH, Peršoh D, Pinruan U, Senanayake IC, Somrithipol S, Suetrong S, Tanaka K, Thambugala KM, Tian Q, Tibpromma S, Udayanga D, Wijayawardene NN, Wanasinghe D, Wisitrassameewong K, Zeng XY, Abdel-Aziz FA, Adamčík S, Bahkali AH, Boonyuen N, Bulgakov T, Callac P, Chomnunti P, Greiner K, Hashimoto A, Hofstetter V, Kang JC, Lewis D, Li XH, Liu XX, Liu ZY, Matsumura M, Mortimer PE, Rambold G, Randrianjohany E, Sato G, Sri-Indrasutdhi V, Tian CM, Verbeken A, Brackel WV, Wang Y, Wen TC, Xu JC, Yan JY, Zhao RL, Camporesi E. 2015 - Fungal Diversity Notes 1-110: Taxonomic and phylogenetic contributions to fungal species. Fungal Diversity 72, 1-197. http://dx.doi.org/10.1007/s13225-015-0324-y

Nylander JAA. 2004 - MrModeltest v2. Program distributed by the author. Evolutionary Biology Center, Uppsala University, Uppsala.

Perrière G, Gouy M. 1996 - WWW-query: an on-line retrieval system for biological sequence banks. Biochimie 78, 364-369. http://dx.doi.org/10.1016/0300-9084(96)84768-7

Photita W, Lumyong P, McKenzie EHC, Hyde KD, Lumyong S. 2002 - A new Dictyosporium species from Musa acuminata in Thailand. Mycotaxon 82, 415-419.

Posada D, Crandall KA. 1998 - MODELTEST: testing the model of DNA substitution. Bioinformatics 14, 817-818. http://dx.doi.org/10.1093/bioinformatics/14.9.817

Ronquist F, Huelsenbeck JP. 2003 - MRBAYES 3: Bayesian phylogenetic inference under mixed models. Bioinformatics 19, 1572-1574. http://dx.doi.org/10.1093/bioinformatics/btg180

Silva CR, Gusmao LFP, Rafael F. Castaneda-Ruiz RF. 2015 - Dictyosporium amoenum sp. nov. from Chapada Diamantina, Bahia, Brazil. Mycotaxon 130, 1125-1133. http://dx.doi.org/10.5248/130.1125

Swofford DL. 2002 - PAUP* 4.0: phylogenetic analysis using parsimony (*and other methods). Sinauer, Sunderland, MA.

Tanaka K, Hirayama K, Yanezawa H, Sato G, Toriyabe A, Kudo K, Hashimoto A, Matsumura M, Harada Y, Kurihara Y, Shirouzu T, Hosoya T. 2015 - Revision of the Massarineae (Pleosporales, Dothideomycetes). Studies in Mycology 82, 75-136. http://dx.doi.org/10.1016/j.simyco.2015.10.002

Thompson JD, Gibson TJ, Plewniak F, Jeanmougin F, Higgins DG. 1997 - The ClustalX windows interface: flexible strategies for multiple sequence alignment aided by quality analysis tools. Nucleic Acids Research 25, 4876-4882. http://dx.doi.org/10.1093/nar/25.24.4876

Tsui CKM, Berbee ML, Jeewon R, Hyde KD. 2006 - Molecular phylogeny of Dictyosporium and allied genera inferred from ribosomal DNA. Fungal Diversity 21, 157-166. 
Vilgalys R, Hester M. 1990 - Rapid genetic identification and mapping of enzymatically amplified ribosomal DNA from several Cryptococcus species. Journal of Bacteriology 172, 42384246.

Whitton SR, McKenzie EHC, Hyde KD. 2012 - Anamorphic fungi associated with Pandanaceae. Fungal Diversity Research Series 21, 125-353. 